\title{
Assessment of Cement Dust Deposit in a Cement Factory in Cotonou (Benin)
}

\author{
Theodore Soussia1,2,3* ${ }^{1,}$ Patient Guedenon ${ }^{3,4}$, Rafiou Lawani2 ${ }^{2}$ Claudia Doutetien Gbaguidi5, \\ Patrick A. Edorh ${ }^{3}$ \\ ${ }^{1}$ Medical and Health National Institute, University of Abomey Calavi, Cotonou, Benin \\ ${ }^{2}$ Military and Teaching Hospital/Center of University Hospital, Cotonou, Benin \\ ${ }^{3}$ Research Laboratory in Biochemistry and Environmental Toxicology, Department of Cell Biology and \\ Biochemistry, Faculty of Science and Technology, University of Abomey Calavi, Cotonou, Benin \\ ${ }^{4}$ School of Health sciences, Houdegbe North American University of Benin, Cotonou, Benin \\ ${ }^{5}$ Faculty of Science of Health, University of Abomey Calavi, Cotonou, Benin \\ Email: soussiatheodore@yahoo.fr
}

Received 27 May 2015; accepted 17 July 2015; published 22 July 2015

Copyright () 2015 by authors and Scientific Research Publishing Inc.

This work is licensed under the Creative Commons Attribution International License (CC BY).

http://creativecommons.org/licenses/by/4.0/

(c) (i) Open Access

\begin{abstract}
In order to assess the cement dust levels at the factory of the Beninese Cement Industry (BCI), at Xwlacodji, seven sampling stations (numbered 1 to 7) were set inside the industry and nine (numbered 8 to 16) were set around the factory in January, February, August and December. With the method of stainless steel plate according to NFX 43-007 AFNOR Standard, the different stations were monitored daily for dust collection all month long. The results revealed that the mean values of cement dusts inside $\mathrm{BCI}$ in $\mathrm{g} / \mathrm{m}^{2} /$ day ranged from 1.608 to 8.752 in January, from 1.13068 to 6.14924 in February, from 0.9654 to 5.2502 for August and from 1.7220 to 9.3620 for December. With regard to outside $B C I$, the mean values of dusts rose from 8.8760 to 18.9620 in December. The lowest mean values 3.2719 and 4.4124 were respectively recorded in February and August whereas the highest values 17.7309 and 18.9620 were respectively recorded in January and December. Our study revealed month variation in cement dust deposition with the highest values in December and January and the lowest values in February and August. It was observed that the content in cement dusts recorded outside the cement industry were extremely higher than those recorded inside the cement industry. The values in the present study have far exceeded all the international safety values $\left(1 \mathrm{~g} / \mathrm{m}^{2} /\right.$ day for AFNOR and $350 \mathrm{mg} / \mathrm{m}^{2} /$ day TA-Luft $)$ and could pose health hazards. Therefore protective measures are suggested to mitigate the risk of occupational hazards for the cement industrial workers.
\end{abstract}

\section{Keywords}

Cement Dust, Factory, Xwlacodji, Health Hazards

\footnotetext{
${ }^{*}$ Corresponding author.
}

How to cite this paper: Soussia, T., Guedenon, P., Lawani, R., Gbaguidi, C.D. and Edorh, P.A. (2015) Assessment of Cement Dust Deposit in a Cement Factory in Cotonou (Benin). Journal of Environmental Protection, 6, 675-682. 


\section{Introduction}

Air is the basic necessity of human life. But it is noticed that the quality of air is deteriorating continuously by constantly pollution of unplanned discharges atmospheric pollutants resulting from intense industrialization, population explosion and urbanization [1]. As a result, the concern about air pollution in urban regions is receiving increasingly importance worldwide, especially pollution by gaseous and particulate trace metals [2]-[5]. In fact, the impact of the atmospheric pollution on the ecosystems was demonstrated at several times [6] [7]. Numbers of epidemiological studies have demonstrated short-term associations between high levels of air pollution and increased acute mortality and morbidity [8]-[10].

In terms of industries, Cement industry occupies a place of choice since it is one of the most basic industries involved in the development of a country as cement is the most widely used building material throughout the world. Its manufacturing has caused environmental impacts at all stages of the process including emissions of airborne pollution in the form of dust, gases, noise and vibration when operating machinery and during blasting in quarries, and damage to countryside from quarrying [11]. The main impacts of the cement activity on the environment are the spread of dusts and gases. In fact, dusts correspond to the main visible pollution generated by the cement industry. Dusts can be emitted at every stage of the manufacturing process of the cement: extraction of the raw material, crushing, production, etc. These particles or dusts are very numerous and varied and can contain various pollutants including particulate matter (Suspended and Respirable), Nitrogen oxides, Sulphur oxides, Carbon monoxide, Volatile organic compounds (VOC) and Green House Gases (GHG); other substances include: Acidic compounds, Heavy metals—Cadmium, Lead, Mercury and Nickel [11]. The deposit of the particles is complex and controlled by the atmospheric stability, the roughness of the surfaces as well as the diameter of the particles [12]. Certainly, the dry deposit of the atmospheric particles is a longer process than the two other types of deposits [7] [13]. The atmospheric particles can have as consequence the reduction of biodiversity and the quality of goods and services offered by the ecosystems.

Moreover, cement factories through their pollutants can have great effect on the environment. The exhaust gases and particulate matters of the dust exhausted from cement plants degrade air quality and thus create considerable environmental pollution. The impacts of cement industry are countless and the exposure to cement pollution has been linked to a number of different health problems, starting from modest transient changes in the respiratory tract and impaired pulmonary function to mortality [14]-[16].

In Benin, there is an exponential increasing demand for cement for building of houses and infrastructures. This has resulted in the proliferation of cement factories in order to meet the supply. It is acknowledged that cement industry is a major source of the imbalances of the environment and producing air pollution hazards. The industry releases huge amounts of cement dusts into the atmosphere which settle on the surrounding areas and cause various adverse effects. The present study is aimed at assessing the cement dusts emitted by Xwlacodji cement industry established in the heart of Cotonou, the economical capital of Benin.

\section{Study Area}

This investigation took place in the factory of the Beninese Cement Industry (BCI) at Xwlacodji. BCI is situated in the 5th district of Cotonou (Republic of Benin) between $2^{\circ} 26^{\prime} 15^{\prime \prime}$ and $2^{\circ} 26^{\prime} 30^{\prime \prime}$ eastern latitude and between $6^{\circ} 21^{\prime} 0$ " and $6^{\circ} 21^{\prime} 5$ " northern longitude. The population of Xwlacodji is about 32,864 [17]. Figure 1 depicts the study area. It comprises sixteen sampling stations set as follows: staff area (station 1), cement loading area (station 2), cement service area (station 3), grinding area (station 4), cement packaging area (station 5), area of storage of raw materials (station 6), magazine for measuring raw materials (station 7) and stations from 8 to 16 are set around the plant. The network of stations is set in December, the period when dust lift-off is facilitated by the dry wind [18].

\section{Materials and Method}

The materials used included stainless steel plate of $50 \mathrm{~mm}^{2}$ for collecting cement dust, silicone oil to bind particles of dust, plastic packaging to protect cement dust samples, a wooden carrier wafer of $2 \mathrm{~m}$, a screwdriver and a scale. The method used was that of stainless steel plate according to NFX 43-007 AFNOR Standard. The plates coated with hydrophobic binder were devices for collecting cement dusts in the atmosphere. The plates were set according to NFX 43-007 AFNOR Standard. The dust particles dropped on the plates by gravitation 


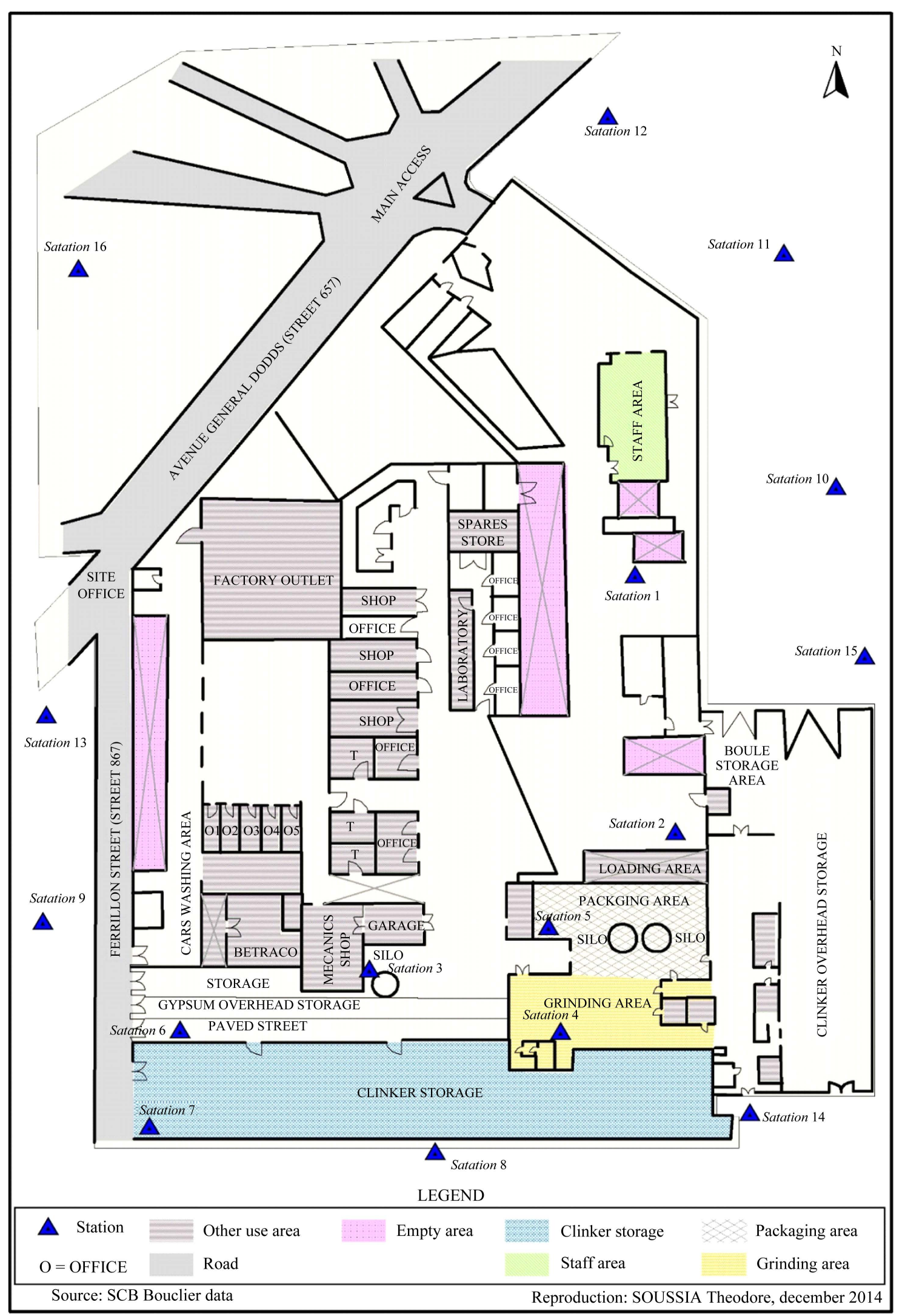

Figure 1. Study area with the different settled stations. 
were retained and stabilized by the coat. The plates were weighed before installation (without particles and plastic packages). Once removed, they were immediately packed in a plastic wrapper to prevent the loss of some particles. The whole was weighed and the mass of dust is obtained by subtracting from the whole the mass of the empty plate and that of the plastic package.

In terms of statistical analyses, cement dust values were expressed as mean \pm SD. Test of Mann Whitney/Wilcoxon at $\mathrm{P}<0.0001$ was carried out to compare the different cement dusts recorded at the different stations inside and outside the factory. Beside student test was conducted to compare the values in this study to the international safety limits.

\section{Results and Discussion}

The content in cement dusts registered at different stations inside the cement plant is gathered in Table 1.

The order of dusts accumulation on the plates at the different stations at all periods of sampling at $\mathrm{P}<0.001$ is as follows: S5 > S2 > S3 > S7 > S6 > S1 > S4 for January, February, August and S5 > S2 > S3 > S7 > S6 > S1 > S4 for December.

The mean values of cement dusts range from 1.608 to 8.752 in January, from 1.13068 to 6.14924 in February, from 0.9654 to 5.2502 for August and from 1.7220 to 9.3620 for December. Inside the cement plant the lowest and the highest mean values were always recorded at stations 4 and 5 respectively. From Table 1, it emerges that the dustiest stations are cement packing area (station 5) and cement loading area (station 2). The less dusty stations are staff area (station 1) and grinding area (station 4).

The values in dusts content recorded outside of the cement industry are gathered in Table 2.

Table 1. Content in cement dusts ( $\mathrm{g} / \mathrm{m}^{2} / \mathrm{day}$ ) recorded at different stations set inside BCI.

\begin{tabular}{|c|c|c|c|c|c|c|c|}
\hline & S1 & S2 & S3 & S4 & S5 & S6 & S7 \\
\hline \multicolumn{8}{|c|}{ January (S5 $>$ S2 $>$ S3 $>$ S7 $>$ S6 $>$ S1 $>$ S4 at $\mathrm{P}<0.001$ ) } \\
\hline Min & 2.168 & 3.85 & 3.822 & 0.788 & 4.292 & 3.256 & 3.7 \\
\hline Max. & 6.618 & 11.752 & 11.67 & 2.408 & 13.102 & 9.938 & 11.294 \\
\hline Mean & 4.42 & 7.85 & 7.796 & 1.608 & 8.752 & 6.638 & 7.544 \\
\hline SD & 1.24 & 2.202 & 2.186 & 0.45 & 2.454 & 1.862 & 2.116 \\
\hline \multicolumn{8}{|c|}{ February (S5 $>$ S2 $>$ S3 $>$ S7 $>$ S6 $>$ S1 $>$ S4 at $\mathrm{P}<\mathbf{0 . 0 0 1 )}$} \\
\hline Min. & 2.17308 & 3.85914 & 3.83194 & 0.79112 & 4.30246 & 3.26334 & 3.70834 \\
\hline Max. & 5.30846 & 9.42722 & 9.36078 & 1.93254 & 10.5102 & 7.97176 & 9.05882 \\
\hline Mean & 3.10584 & 5.51562 & 5.47674 & 1.13068 & 6.14924 & 4.66406 & 5.30008 \\
\hline SD & 0.76158 & 1.35248 & 1.34294 & 0.27726 & 1.50784 & 1.14368 & 1.29962 \\
\hline \multicolumn{8}{|c|}{ August (S5 $>$ S2 $>$ S3 $>$ S7 $>$ S6 $>$ S1 $>$ S4 at $\mathrm{P}<0.001$ ) } \\
\hline Min. & 1.8792 & 3.3373 & 3.3138 & 0.6841 & 3.7207 & 2.8221 & 3.2069 \\
\hline Max. & 4.7945 & 8.5145 & 8.4545 & 1.7454 & 9.4927 & 7.2000 & 8.1818 \\
\hline Mean & 2.6518 & 4.7092 & 4.6760 & 0.9654 & 5.2502 & 3.9822 & 4.5252 \\
\hline SD & 0.5924 & 1.0520 & 0.2157 & 1.1729 & 0.8896 & 1.0109 & 1.6016 \\
\hline \multicolumn{8}{|c|}{ December (S5 $>$ S2 $>$ S3 $>$ S7 $>$ S6 $>$ S1 $>$ S4 at $\mathrm{P}<0.001$ ) } \\
\hline Min. & 1.2860 & 2.2820 & 2.2660 & 0.4680 & 2.5440 & 1.9300 & 2.1940 \\
\hline Max. & 13.2100 & 23.4540 & 23.2900 & 4.8100 & 26.1480 & 19.8340 & 22.5360 \\
\hline Mean & 4.7280 & 8.3960 & 8.3380 & 1.7220 & 9.3620 & 7.1000 & 8.0680 \\
\hline SD & 3.2140 & 5.7100 & 5.6680 & 1.1700 & 7.1000 & 4.8280 & 5.4860 \\
\hline
\end{tabular}


Table 2. Content in cement dusts ( $\mathrm{g} / \mathrm{m}^{2} /$ day) recorded at different stations set outside BCI.

\begin{tabular}{|c|c|c|c|c|c|c|c|c|c|}
\hline & S8 & S9 & S10 & S11 & S12 & S13 & S14 & S15 & S16 \\
\hline \multicolumn{10}{|c|}{ January (S14 $>$ S10 $>$ S9 $>$ S16 $>$ S12 $>$ S15 $>$ S8 $>$ S13 $>$ S11 at $\mathrm{P}<0.001)$} \\
\hline Min & 4.66246 & 7.696 & 8.38666 & 4.07 & 5.67334 & 4.588 & 8.695 & 5.95902 & 6.43078 \\
\hline Max. & 14.23202 & 23.49176 & 25.6 & 12.42352 & 17.31764 & 14.0047 & 26.54118 & 18.35004 & 19.62976 \\
\hline Mean & 9.50772 & 15.693738 & 17.10214 & 8.29956 & 11.5691 & 9.35588 & 17.7309 & 10.66112 & 13.1137 \\
\hline SD & 2.66672 & 4.401752 & 4.79678 & 2.32784 & 3.24488 & 2.62412 & 4.97314 & 0.8932 & 3.67812 \\
\hline \multicolumn{10}{|c|}{ February (S14 > S8 > S16 > S12 > S10 > S15 > S11 > S13 > S9 at P $<0.001)$} \\
\hline Min. & 6.3418 & 2.2892 & 4.1780 & 2.9017 & 4.4500 & 2.3733 & 8.8629 & 3.2226 & 5.1792 \\
\hline Max. & 15.4921 & 5.5923 & 10.2062 & 7.0885 & 10.8706 & 5.7976 & 21.6506 & 7.8723 & 12.6520 \\
\hline Mean & 9.0640 & 3.2719 & 5.9714 & 4.1473 & 6.3601 & 3.3920 & 12.6672 & 4.6059 & 7.4023 \\
\hline SD & 2.2225 & 0.8023 & 1.4642 & 1.0169 & 1.5596 & 0.8318 & 3.1061 & 1.1294 & 1.8151 \\
\hline \multicolumn{10}{|c|}{ August $(\mathrm{S} 14>\mathrm{S} 10>\mathrm{S} 9>\mathrm{S} 16>\mathrm{S} 12>\mathrm{S} 15>\mathrm{S} 8>\mathrm{S} 13>\mathrm{S} 11$ at $\mathrm{P}<0.001)$} \\
\hline Min. & 4.0411 & 6.6703 & 7.2690 & 3.5276 & 4.9172 & 3.9766 & 7.5362 & 2.3888 & 5.5737 \\
\hline Max. & 10.3101 & 17.0182 & 18.5454 & 9.0000 & 12.5455 & 10.1454 & 19.2273 & 14.2204 & 14.2204 \\
\hline Mean & 5.7023 & 9.4124 & 10.2571 & 4.9777 & 6.9387 & 5.6113 & 10.6342 & 6.8862 & 7.8650 \\
\hline SD & 1.2739 & 2.1027 & 2.2914 & 1.1120 & 1.9972 & 1.2535 & 2.3757 & 2.8861 & 1.7570 \\
\hline \multicolumn{10}{|c|}{ December $(\mathrm{S} 14>\mathrm{S} 10>\mathrm{S} 9>\mathrm{S} 16>\mathrm{S} 12>\mathrm{S} 15>\mathrm{S} 8>\mathrm{S} 13>\mathrm{S} 11$ at $\mathrm{P}<0.001)$} \\
\hline Min. & 2.7640 & 4.5620 & 4.9720 & 2.4120 & 3.3640 & 2.7200 & 5.1540 & 2.8320 & 3.5980 \\
\hline Max. & 28.4020 & 46.8780 & 51.0840 & 24.7900 & 34.5560 & 27.9460 & 52.9660 & 29.0980 & 36.9660 \\
\hline Mean & 10.1680 & 16.7840 & 18.2900 & 8.8760 & 12.3720 & 10.0060 & 18.9620 & 10.4180 & 13.2340 \\
\hline SD & 6.9140 & 11.4100 & 12.4340 & 6.0340 & 8.4120 & 6.8020 & 12.8920 & 7.0820 & 8.9980 \\
\hline
\end{tabular}

The patterns of adsorption of dust particles on the plates are S14 $>$ S10 $>$ S9 $>$ S16 $>$ S12 $>$ S15 $>$ S8 $>$ S13 $>$ $\mathrm{S} 11, \mathrm{~S} 14>\mathrm{S} 8>\mathrm{S} 16>\mathrm{S} 12>\mathrm{S} 10>\mathrm{S} 15>\mathrm{S} 11>\mathrm{S} 13>\mathrm{S} 9, \mathrm{~S} 14>\mathrm{S} 10>\mathrm{S} 9>\mathrm{S} 16>\mathrm{S} 12>\mathrm{S} 15>\mathrm{S} 8>\mathrm{S} 13>$ $\mathrm{S} 11, \mathrm{~S} 14>\mathrm{S} 10>\mathrm{S} 9>\mathrm{S} 16>\mathrm{S} 12>\mathrm{S} 15>\mathrm{S} 8>\mathrm{S} 13>\mathrm{S} 11$ respectively for January, February, August and December at $\mathrm{P}<0.001)$.

In December, the mean values of dusts rose from 8.8760 (station 11) to 18.9620 (station 14). The lowest mean values 3.2719 (Station 9) and 4.4124 (Station 9) were respectively recorded in February and August whereas the highest values 17.7309 (Station 14) and 18.9620 (Station 14) were respectively recorded in January and December. Although the patterns of dusts accumulation on the plates are not the same, station 14 remained the dustiest station at all periods whereas station 11 recorded the lowest values in January, August and December.

Moreover, the dust mean values recorded in December and January were much higher than those recorded in February and August leading to the inference that December and January were the dustiest months whereas February and August are the least dusty months inside as well as outside the cement factory.

Comparison of the dust mean values from BCI with international values revealed that the present values are much higher than those reported by Toulouse annual report, ORAMIP and Henni-Chebra et al. [19] [20] with mean values ranging from $67 \mathrm{mg} / \mathrm{m}^{2} /$ day to $91 \mathrm{mg} / \mathrm{m}^{2} /$ day, from 35 to $123 \mathrm{mg} / \mathrm{m}^{2} /$ day and from 15 to 107 $\mathrm{mg} / \mathrm{m}^{2} /$ day respectively. However, our values are far lower than those recorded by Western Australian Department Of Health rising from 25 to $381 \mathrm{~g} / \mathrm{m}^{2} / \mathrm{month}$.

The present study suggested that the highest mean values were recorded at packing station in contrast to station at administration level which recorded the lowest mean values. Similar observations were reported by Kakooei et al. [21] who registered higher values in the crusher $\left(20.84 \mathrm{mg} / \mathrm{m}^{3}\right)$ and packing $\left(17.29 \mathrm{mg} / \mathrm{m}^{3}\right)$, compared to low values $3.77 \mathrm{mg} / \mathrm{m}^{3}$ and $1.01 \mathrm{mg} / \mathrm{m}^{3}$ for the maintenance and administration parts respectively. The 
same observation was reported by Kromhout [22] and Mwaiselage et al. [23]. Hence workers in packing, had markedly higher exposure than others.

Our study revealed month variation in cement dust deposition with the highest values in December and January and the lowest values in February and August. This report is in accordance with the results of Mehraj et al. [24] and Anglauf et al. [25]. This monthly variation could be in general attributable to variations in wind speed and wind direction. In fact, December and January in Benin are the winter months when Harmattan is the most manifested promoting dust lift-off and their adsorption.

The comparison of the values of cement dusts recorded inside the cement plant with those recorded outside and the international safety values (AFNOR $=1 \mathrm{~g} / \mathrm{m}^{2} /$ day and TA-Luft $=350 \mathrm{mg} / \mathrm{m}^{2} /$ day) is plotted on Figure 2 .

From Figure 2 and statistical analyses, it emerges that the content in cement dusts recorded outside the cement industry are extremely higher than those recorded inside the cement industry. Many other sources could have contributed to the elevated levels of dust particles recorded outside the Beninese cement industry. In fact, the particularity of the cement factory in study is that it is located at the heart of Cotonou and surrounded by intense traffics and activities which generate significant dust like particles resulting in increasing the levels of cement dusts from the factory.

Besides, it is also noted that all the international safety values $\left(1 \mathrm{~g} / \mathrm{m}^{2} /\right.$ day for AFNOR and $350 \mathrm{mg} / \mathrm{m}^{2} /$ day TA-Luft) are far exceeded.

The levels of cement dusts and the frequencies and amplitudes of exceeding the permissible limits have farreaching implications directly or indirectly to man.

In fact, numerous epidemiological studies associated a variety of pathologies with cement dust exposure. Several studies have demonstrated linkages between cement dust exposure, chronic impairment of lung function and respiratory symptoms in human population. [14] [23] [26] [27]. According to the authors, total cement dust exposure has been found to be related to acute respiratory symptoms and acute ventilatory effects. Its deposition in the respiratory tract causes a basic reaction leading to increased $\mathrm{pH}$ values that irritates the exposed mucous membranes.

Also, cement dust has been identified as an eye allergen and can cause runny eyes, and Conjunctivitis [27][30]. Soussia et al. [1] found acute and chronic eye conditions among workers people at a Portland cement plant.

Additionally, Dolgner et al. [31] have demonstrated that cement dust generated during cement production causes congenital malformation in the population living in the vicinity of the cement plant. These congenital abnormalities were cleft lip and palate, facial hemangioma, icterus neonatorum, swelling on the back of hands and feet, inguinal hernia, umbilical hernia, lumbar meningomyelocele and ventricular septal defect.

Besides, there is an association between cement dust and genetic damages. Fatima et al. [32] have reported

Data 1

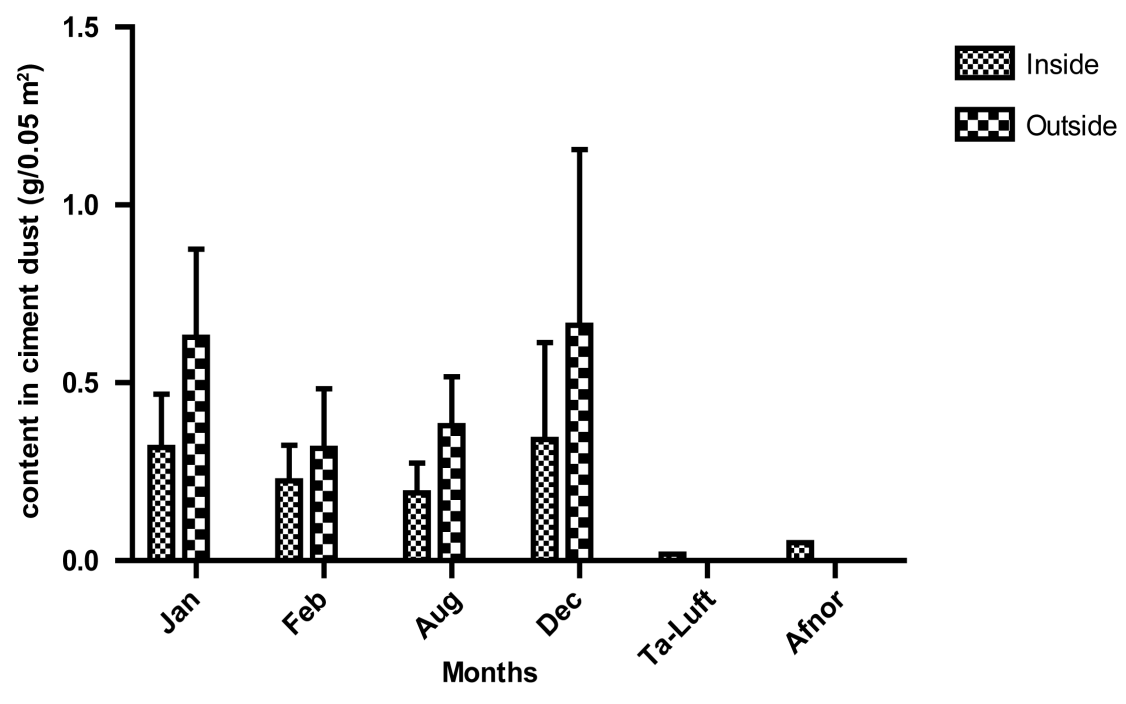

Figure 2. Comparison among cement dusts inside BCI, outside BCI and international standards. 
mutagenic effects of occupational exposure to cement dust such as chromosomal damage, chromosomal aberrations in workers.

Moreover, cement dust could cause heat impairment. Actually, Maciejewska [33] induced siliceous dust by intra-tracheal administration in rats and found an increased level of collagen due to fibrosis in heart of the rats. The findings of this animal study indicate that silica is deposited in heart when introduced by intra-tracheal route and caused fibrosis; hence the collagen contents are increased in the heart.

\section{Conclusion}

The present study reveals high level of cement dust at all stations inside and outside the Beninese Cement Industry exceeding all the international permissive values. It poses public and occupational health hazards. Therefore, workers and health officials should work together to adopt preventive measures, such as well-ventilated work areas, use of appropriate uniform, mask, safety goggles for effective protection. It is also suggested that workers must undergo periodic medical surveillance tests. These measures would help to mitigate the risk of occupational hazards for the cement industrial workers.

\section{References}

[1] Soussia, T., Guedenon, P., Koumassi, H., Lawani, R., Edorh, P.A. and Doutetien Gbaguidi, C. (2014) Oculopathy within Workers of Beninese Cement Industry of Xwlacodji (BCI) in Cotonou (Benin). International Research Journal of Public and Environmental Health, 1, 158-164.

[2] Azad, A.K. and Kitada, T. (1998) Characteristics of the Air Pollution in the City of Dhaka, Bangladesh in Winter. Atmospheric Environment, 32, 1991-2005. http://dx.doi.org/10.1016/S1352-2310(97)00508-6

[3] Salam, A., Bauer, H., Kassin, K., Ullah, S.M. and Puxbaum, H. (2003) Aerosol Chemical Characteristics of a MegaCity in Southeast Asia (Dhaka, Bangladesh). Atmospheric Environment, 3, 2517-2528. http://dx.doi.org/10.1016/S1352-2310(03)00135-3

[4] Begum, B.A., Kim, E., Biswas, S.K. and Hopk, P.K. (2004) Investigation of Sources of Atmospheric Aerosol at Urban and Semi-Urban in Bangladesh. Atmospheric Environment, 38, 3025-3038. http://dx.doi.org/10.1016/j.atmosenv.2004.02.042

[5] Cachier, H., Aulagnier, F., Sarda, R., Gautier, F., Masclet, P. and Besombes, J.L. (2005) The ESCOMPTE Experiment: 108. Air Quality, Atmosphere and Health, 1, 101-109.

[6] Bliefert, C. and Perraud, R. (2001) Chimie de l'environnementair, eau, sols, déchets. De Boeck Diffusion, Paris, 359365.

[7] Grantz, D.A., Garner, J.H.B. and Johnson, D.W. (2003) Ecological Effects of Particulate Matter. Environment International, 29, 213-239. http://dx.doi.org/10.1016/S0160-4120(02)00181-2

[8] Lippmann, M., Ito, K., Nádas, A. and Burnett, R.T. (2000) Association of Particulate Matter Components with Daily Mortality and Morbidity in Urban Populations. Research Report (Health Effects Institute), 95, 5-72.

[9] Katsouyanni, K., Touloumi, G., Samoli, E., Gryparis, A., Le Tertre, A., Monopolis, Y., Rossi, G., Zmirou, D., Ballester, F., Boumghar, A., Anderson, H.R., Wojtyniak, B., Paldy, A., Braunstein, R., Pekkanen, J., Schindler, C. and Schwartz, J. (2001) Confounding and Effect Modification in the Short-Term Effects of Ambient Particles on Total Mortality: Results from 29 European Cities within the APHEA2 Project. Epidemiology, 12, 521-531. http://dx.doi.org/10.1097/00001648-200109000-00011

[10] Petroeschevsky, A, Simpson, R.W., Thalib, L. and Rutherford, S. (2001) Associations between Outdoor Air Pollution and Hospital Admissions in Brisbane, Australia. Archives of Environmental Health: An International Journal, 56, 37-52. http://dx.doi.org/10.1080/00039890109604053

[11] Mehraj, S.S. and Bhat, G.A. (2014) Cement Factories, Air Pollution and Consequences. Jammu and Kashmir, India.

[12] Hosker, R.P. and Lindberg, S.E. (1982) Review Article: Atmospheric Deposition and Plant Assimilation of Airborne Gases and Particles. Atmospheric Environment, 16, 889-910. http://dx.doi.org/10.1016/0004-6981(82)90175-5

[13] Hicks, B.B. (1986) Differences in Wet and Dry Particle Deposition Parameters between North America and Europe. In: Lee, S.D., Schneider, T., Grant, L.D. and Verkerk, P.J., Eds., Aerosols: Research, Risk Assessment, and Control Strategies, Proceedings of the 2nd US-Dutch Symposium, Williamsburg, 19-25 May 1985, Lewis Publishers, Chelsea, 973982.

[14] Zeleke, Z.K., Moen, B.E. and Bråtveit, M. (2010) Cement Dust Exposure and Acute Lung Function: A Cross Shift Study. BMC Pulmonary Medicine, 10, 19. http://dx.doi.org/10.1186/1471-2466-10-19

[15] Schuhmacher, M., Domingo, J.L. and Garreta, J. (2004) Pollutants Emitted by a Cement Plant: Health Risks for the 
Population Living in the Neighborhood. Environmental Research, 9, 198-206. http://dx.doi.org/10.1016/j.envres.2003.08.011

[16] Aydin, S., Aydin, S., Croteau, G., Sahin, I. and Citil, C. (2010) Ghrelin, Nitrite and Paraoxonase/Arylesterase.

[17] Attanasso, M.O. (2007) Rapport du Recensement sur les Conditions D’existence des Ménages du 13e Arrondissement de Cotonou. 6th PEP Research Network General Meeting, Lima, 14-16 June 2007.

[18] ASECNA (2013) Rapport annuel: Hauteur d'eau recueillie en mm à Cotonou.

[19] ORAMIP (2012) Rapport annuel, suivi de la qualité de l’air autour de sites industriels de Midi Pyrénées. http://www.oramip.org

[20] Henni-Chebra, K., Bougara, A. and Kadri, E. (2011) Détermination du niveau d’empoussièrement engendrée par la fabrication du ciment. XXIXe Rencontres Universitaires de Génie Civil, Tlemcen, 29 au 31 Mai 2011.

[21] Kakooei, H., Kakouei, A.A., Poornajaf, A. and Ferasaty, F. (2012) Variability in Total Dust Exposure in a Cement Factory. Industrial Health, 50, 64-68. http://dx.doi.org/10.2486/indhealth.MS1311

[22] Kromhout, H. (2002) Design of Measurement Strategies for Workplace Exposure. Occupational and Environmental Medicine, 59, 349-354. http://dx.doi.org/10.1136/oem.59.5.349

[23] Mwaiselage, J., Bråtveit, M., Moen, B. and Mashalla, Y. (2006) Cement Dust Exposure and Ventilatory Function Impairment: An Exposure-Response Study. Journal of Occupational \& Environmental Medicine, 46, 658-667. http://dx.doi.org/10.1097/01.jom.0000131787.02250.79

[24] Mehraj, S.S., Bhat, G.A., Balkhi, H.M. and Gul, T. (2013) Health Risks for Population Living in the Neighborhood of a Cement Factory. African Journal of Environmental Science and Technology, 7, 1044-1052.

[25] Anglauf, K.G., Boltenheim, J.W., Brice, K.A. and Wiebe, H.A. (1986) A Comparison of Summer and Winter Measurements of Atmospheric Nitrogen and Sulphur Compounds. Water, Air and Soil Pollution, 30, 163-160.

[26] Al-Neaimi, Y.I., Gomes, J. and Lloyd, O.L. (2001) Respiratory Illnesses and Ventilatory Function among Workers at a Cement Factory in a Rapidly Developing Country. Occupational Medicine, 51, 367-373. http://dx.doi.org/10.1093/occmed/51.6.367

[27] Adak, M.D., Adak, S. and Purohit, K.M. (2007) Ambient Air Quality and Health Hazards Near Mini Cement Plants. Pollution Research, 26, 361-364.

[28] Rozanova, E., Heilig, P. and Godnić-cvar, J. (2009) The Eye-A Neglected Organ in Environmental and Occupational medicine: An Overview of Known Environmental and Occupational Non-Traumatic Effects on the Eyes. Environmental \& Occupational Non-Traumatic Effects on the Eyes. Archives of Industrial Hygiene and Toxicology, 60, 205215. http://dx.doi.org/10.2478/10004-1254-60-2009-1869

[29] Lu, P., Chen, X., Liu, X., Yu, L., Kang, Y., Xie, Q. and Wei, X. (2008) Dry Eye Syndrome in Elderly Tibetans at High Altitude: A Population-Based Study in China. Cornea, 27, 545-551. http://dx.doi.org/10.1097/ICO.0b013e318165b1b7

[30] Novaes, P., do Nascimento Saldiva, P.H., Kara-José, N., Macchione, M., Matsuda, M., Racca, L. and Berra, A.A. (2007) Ambient Levels of Air Pollution Induce Goblet-Cell Hyperplasia in Human Conjunctival Epithelium. Environmental Health Perspectives, 115, 1753-1756. http://dx.doi.org/10.1289/ehp.10363

[31] Dolgner, R., Brockhaus, A., Ewers, U., Weigand, H., Majewski, F. and Soddemann, H. (1983) Repeated Surveillance of Exposure to Thallium in a Population Living in the Vicinity of a Cement Plant Emitting Dust Containing Thallium. International Archives of Occupational and Environmental Health, 52, 79-94. http://dx.doi.org/10.1007/BF00380610

[32] Fatima, S.K., Prabhavathi, P.A., Padmavathi, P. and Reddy, P.P. (2001) Analysis of Chromosomal Aberrations in Men Occupationally Exposed to Cement Dust. Mutation Research/Genetic Toxicology and Environmental Mutagenesis, 490, 179-186. http://dx.doi.org/10.1016/S1383-5718(00)00165-0

[33] Maciejewska, A. (1987) Experimental Silicosis. Analysis of Collagen Levels in the Heart, Spleen and Liver of Rats in Experimental Silicosis. Medycyna Pracy, 38, 45-54. 